\title{
Reversing silences in West Papua Interdisciplinary research and (audio) documentary
}

\begin{abstract}
Journalism about West Papua is in many ways an act of translation. It involves not only translating between languages, but also disciplines, audiences and knowledges. This article examines how interdisciplinary research — such as anthropology and history — might intersect with journalism as a means to understand and challenge existing gaps in translation, or 'silences' about West Papua in the past and present. It also reflects on how audio documentaries carry out such translation work on misunderstood and underreported issues. To illustrate this, the author reflects on the process of making the audio documentary \#Illridewithyou, West Papua for ABC Radio National's Earshot documentary programme as well as a companion longform article for the ABC's website.
\end{abstract}

Keywords: anthropology, audio, documentary, Frontline, history, human rights, Indonesia, interdisciplinary research, investigative journalism, journalism as research, West Papua

\section{BELINDA LOPEZ}

Independent researcher, Sydney

\section{Silences in West Papuan history and journalism}

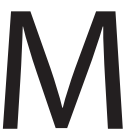

$\mathrm{Y}$ anecdotal evidence for how poorly West Papua ${ }^{1}$ is understood by my fellow Australians is this: whenever I mention I have an interest in the region, at least half the time, in response, someone will mention Papua New Guinea instead. Which is often why the infrequent reporting on the topic in the international media usually comes with a mandatory one or two paragraph attempt to bring the audience up to speed with West Papuan modern history and politics, to understand why the current news matters.

In August 2019, the largest protests about West Papua seen in decades started in Java and spilled out throughout Indonesia. I realised that I might be able to create a long-form journalism project that could explore the roots of this 
discontent, not in a paragraph aside but as a framing question about the recent and not-so-recent past. I felt an urgency in doing so, given the media portrayals and censorship of Papuans, community violence and heavy state response to the uprisings (Human Rights Watch, 2020).

When it comes to West Papua, I am also interested in what Haitian anthropologist Michel-Rolph Trouillot (1995) describes as the production of silences in the historical narrative. He argues that such silences are about power-they do 'not require a conspiracy, not even a political consensus. Its roots are structural' (p. 105). These ideas have emerged in parallel in West Papua. Theologian, writer and anthropologist Benny Giay (2006) describes the social fabric of such structural productions of silences as budaya bisu (a mute or silent culture), which ensures these absences endure because of trauma and oppression.

I approach Trouillot's work primarily via Chris Nash (2016), who expands this concern to silences and absences in the media, 'the norm for those not in a position to exercise power in the world of journalism' (p. 147). It is a situation that again materialises in Indonesia and beyond about West Papua, as this article will reflect on further.

Nash's book What is Journalism? devotes itself to two interdisciplinary practitioners, Hans Haacke and I.F. Stone, whose work challenged structural power. They were 'in Trouillot's terms... taking a position to reverse an existing silence by producing objects able to be perceived by audiences' (Nash, 2016, p. 150).

West Papuans have long sought to reverse such silences in their colonial past and present. They have done so through both a longstanding culture of oral storytelling, and a new generation of journalists and thinkers grappling with these ideas through writing and discussion (Lopez, 2019).

Giay is the leading example of many Papuan interdisciplinary writer-scholars guided by the work of theologian Johann Baptist Metz, whose memoria passionis aims to contend with 'the "silent history" of the colonised and enslaved' (my translation) (Giay, 2006, p. 24). His work of longform journalism, Pembunuhan Theys (The Murder of Theys) (2006), documents the life and death of Theys Eluay, a Papuan man who served as a parliamentarian for the ruling party during the Suharto era. While initially helping the Indonesian state track down West Papuan independence activists, he later emerged as a leading figure for independence himself, before being killed by Indonesian security forces (Kirksey, 2012).

In West Papua, daring to work to reverse such silences can carry great consequences, including threats to lives and livelihoods (Lopez, 2019). Giay's experience is no different. Among other threats, the first edition of Pembunuhan Theys was removed from circulation and banned a month after its release by local authorities, who described the book as 'disturbing to the public' (Giay, 2006, p. 9).

Reportage outside of West Papua may also reverse such silences, through journalistic translation. I do not only mean translation between languages, 
although this is often needed. In reportage about West Papua, it is not enough simply to reverse the silence - the silence itself must be explained. The media, political and historical blackout of West Papua has been so successful, many international audiences may not even be aware of the existing narrative where the absence exists. Language, identity, and - most importantly - the past must be contextualised, which is why that seemingly mandatory two-paragraph backgrounder on history is found in nearly every international current affairs article on West Papua.

We might consider this translation work in terms of the 'maps of meaning' articulated by Stuart Hall et al. in Policing the Crisis: Mugging, the State, and Law and Order (1982; see also Nash, 2016, p. 142). They argue that newsworthy events are "brought into the horizon of the "meaningful" - in that these events are added to "maps of meaning" which already form the basis of our cultural knowledge' (p. 54). Making an event 'intelligible' is a social process made possible through journalistic practices 'which embody (often only implicitly) crucial assumptions about what society is and how it works' (p. 55). This journalistic 'mapping' process I argue is one of translation, particularly when an audience has to learn both about silences and the stories that should fill them, as well as the patchwork of historical and political narratives previously used to cover them up.

Yet just as a journalist makes West Papua 'meaningful' for an audience, she too must preserve and respect original meanings and knowledges. This too requires careful translation work. Anthropologist Eben Kirksey (2012) invokes feminist theorist Donna Haraway to describe how West Papuan 'situated knowledges' are translated into 'the view from nowhere'-'a disembodied form of vision that claims to see everything from nowhere'-found in both NGO reports and some forms of journalism, including the investigative journalism articles he wrote based on his fieldwork and interviews about West Papua (p. 134). He also describes this as a translation project, in line with Haraway's call to 'translate knowledges among very different - and power-differentiated-communities' (Kirksey, 2012, p. 134; Haraway, 1988, p. 588). This is also about mapping: Haraway (1988) argues that 'a map of tensions and reasonances between the fixed ends of a charged dichotomy better represents the potent politics and epistemologies of embodied, therefore accountable, objectivity' (p. 588). In journalistic terms, this means a reflective kind of reportage that explores and documents complexity, contradictions and power relations in all its forms, an aim that does not have to be incongruous with mapping meaning for an audience. 


\section{Part 1: The exegesis \\ Translating West Papua's past and present}

I first pitched the idea of a documentary to the ABC in 2019, not long after the West Papua protests that year appeared in international headlines. During the previous four years, I had conducted doctoral research exploring how West Papuans encounter stories from the past and present in Java, Indonesia. My research analysed the purpose and impact of Papuan stories and storytelling, particularly about history, by fusing several narrative methodologies defined by non-Indigenous and First Nations' scholars (Lopez, 2019).

Yet Chris Nash (2016) argues, the 'sine qua non of successful journalism is to have the most up-to-date information to report and analyse... to be operating at the cutting edge of the present as distinct from the past or future" (p. 137). My doctoral research was not 'up to date' in a current affairs sense, and it had employed ethnographic or anthropological methodologies as opposed to traditional journalistic ones - and I will endeavour to dig into these distinctions further. Before and after my doctoral studies I worked as an audio documentary maker, for the Australian Broadcasting Corporation and other local and international outlets. Much of my previous work has comprised narrative-led audio documentaries on human rights and social justice issues. In that sense my ethical code was also one of a journalist's - in as much as journalism's public morality involves getting an important story out, and doing so by addressing a public and using a 'public voice' (Nash, 2016, p. 227).

Of the many people I spoke to during that time, I thought almost instantly about a specific incident, and a few participants that might translate into a story and characters in an audio documentary on the subject. I realised that my original longterm anthropological/ethnographic research could became another source I could employ in the pursuit of my journalistic aims. It was a source that needed to be supplemented with further research, in order for it to be considered journalism. Part of the measure of the success of my audio documentary would be how I translated or 'interpreted the materials [I had] brought to light' (Meadows in Bacon, 2012, p. 156) - including my own research data. First, I needed to formulate a question, "the answer to which is the answer to "What's the story?", (Nash, 2013, pp. 127-129).

I question myself whether I could ever really switch off my journalistic radar for my anthropological research, and of course the two fields employ participant observation, interviews and fieldwork as part of their methodological tool kits (Nash, 2013, p. 129). Anna Tsing writes that fieldwork represents the rhythms, or 'exceptional outpouring of the everyday. The story presents us with repetition, and then surprise' (Tsing \& Ebron, 2015, p. 685). This 'seeps and bubbles into partially formed consciousness - and analysis and theory are informed' ( $p$. 683) — and I would argue, allows the researcher to be better placed to find stories 
and form questions for further (journalistic) research. Another way of describing this is habitus, and Chris Nash (2016) suggests that Pierre Bourdieu's concept might be useful to explain 'real time intuition' in journalism, or 'news sense' (p. 171) - in other words, my journalistic radar. He also concludes that journalism research can be thought of in relation to other disciplines, 'and therefore disciplinarily should be understood not as a series of barriers but as a basis for mutual exchange and collaboration' (Nash, 2016, p. 234). Thinking of the inherent interdisciplinarity of habitus presents opportunities for translation across methodologies, outputs and audiences.

The techniques I employed in my original ethnographic research, including indepth interviewing, observation and sound recording, also happen to be key elements in audio documentary, the genre or style of journalism in which I have most professional experience. I also gained approval from participants for their interviews to appear in various formats beyond scholarly articles, including audio documentaries, feature articles and books, long before I had conceived how these outputs might take shape. Similarly, after conducting ethnographic research into how remorse is judged in the NSW criminal justice system, writer-ethnographer Kate Rossmanith (2013) found herself considering her options while looking at her field notes: 'My mind immediately turned to genres: I can write academic articles, I thought to myself, and I can also write literary nonfiction' (p. 7)—of course, a form of journalism in its own right. However, my anthropological ethnographic research data was a knowledge base or source/s upon which I had to formulate further journalistic questions.

The audio documentary is its own distinct form of journalism that unlike other genres is less focused on breaking news, and in that way I would argue better suited to adapt the data produced from ethnographic fieldwork and interviewing. Journalist-academics Mia Lindgren and Gail Phillips (2015) write that 'while deploying skills familiar in oral history and sociology methodologies, the power of the story and specifically its crafting to maximise its appeal to a future audience is what distinguishes journalism as a discipline' (p. 169). I would argue the practitioners of documentary, investigative and research journalism are more likely to have the capacity to apply indepth methodologies, compared to the vast majority of journalism, increasingly deprived of resources and often pegged to a 24-hour news cycle (Bacon, 2011; Lynch, 2013).

Answering 'What's the story?' occurred in reverse throughout my ethnographic research - 'Aha, here's a story!'-when I often heard an angle, experience or information I felt could be the opening lines of a pitch, or develop into a distinct or expanded journalism research question. The title of the audio documentary featured in this article is a case in point. During my research in 2015, I was interviewing Indonesian activist Zely Ariane, who, while describing her experiences of working with West Papuans on human rights issues in Jakarta, 
told me a story that caught the attention of my journalistic radar (clearly, it does not have an off switch).

A year earlier, Ariane had tried to raise awareness about the killing of teenagers by Indonesian security forces in Paniai, West Papua, by tying it to a phenomenon that had originated almost at the same time in Sydney and had made international news. Her plan was to use the hashtag \#illridewithyou, which went viral worldwide on social media in response to the Lindt cafe terrorist attack. The hashtag aimed to show solidarity with Australian Muslims, who feared a backlash after the gunman Man Monis had depicted the Shahada, the Muslim declaration of faith, and claimed it was an attack on Australia by the terrorist organisation Islamic State (State Coroner of NSW, 2017). Ariane came up with the idea of a poster that read \#illridewithyou \#Paniai \#West Papua, as a means of making the killings in Paniai 'translatable' into solidarity for Papuan grievances, since her fellow Indonesians appeared to be showing far more interest in \#illridewithyou than the deaths of teenagers in their own country. Activists in Jakarta responded to the Paniai incident by forming a movement called Papua Itu Kita (Papua is Us), that when I first spoke to Ariane in 2015, was only just gaining ground. That \#illridewithyou poster was their first logo on social media.

Aha! I remember thinking during that interview that \#illridewithyou was an angle that was translatable to an Australian audience-it was a definable point on an existing 'map of meaning'. In real time during the interview (which took place about a year after the Paniai incident) I was also formulating questions about what this story was: Why had nobody been made accountable for the teenagers' deaths? Why was there so little interest in what had happened? As a researcher and professional working in and occasionally studying the media, I was also interested in what the story illustrated about why and how some events are elevated above others in the news, and the power dynamics that come into play to facilitate that. Within that same ethnographic interview, I then pursued a line of detailed questioning with Ariane that I subconsciously knew would allow me to use this interview in both a scholarly output, as well as a narrative that could be experienced by an audience, even as I had no plans to create a documentary at that moment. As an audio documentary maker with an anthropologist's hat on (and at times, vice versa), I had somewhat subconsciously adopted dual modes of listening, as Rob Anderson and George Killenberg (1992) describe: 'Listening to a person and listening for a story that the public needs to know about may be somewhat separate, perhaps contradictory, and often ambiguous tasks for an interviewer' (p. 73) - perhaps a kind of 'habitus of listening'. Becker (2004, p. 71) uses the term adopted from Bourdieu to reflect on how musical emotion is perceived, but we can also use it to think about how interdisciplinary researchers and storytellers listen in particular and tacit ways, and to reflect on the conscious translation work that is needed to share this knowledge with different audiences. 


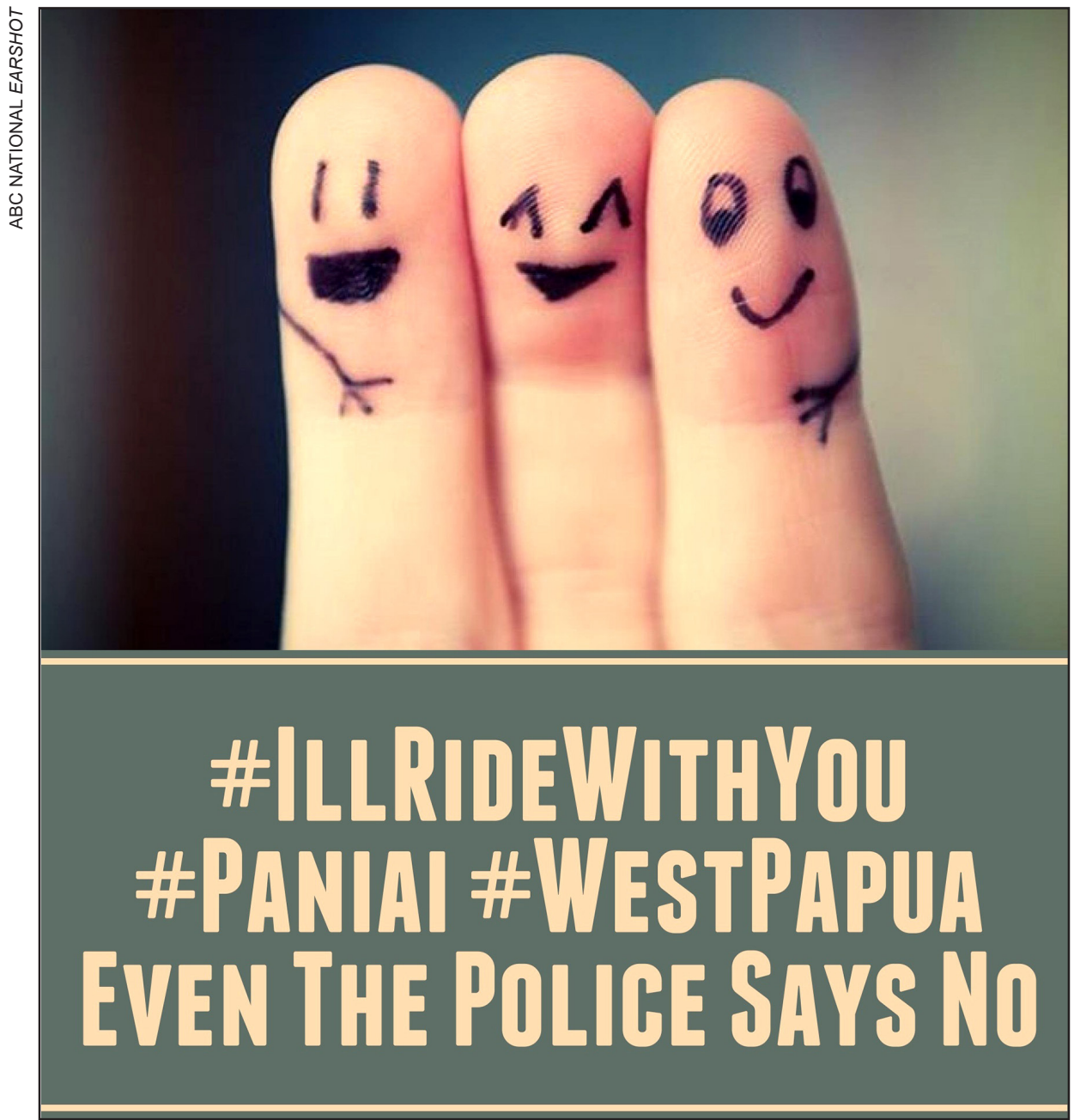

Figure 1: The \#illridewithyou poster was the Papua Itu Kita group's first logo on social media.

If journalism is described as the first draft of history, then it can also be thought of as 'the first draft of memory, a statement about what should be considered, in the future, as having mattered today' (Kitch in Lindgren \& Philips, 2015, p. 161) or of having helped decide what is 'of contemporary significance' (Nash, 2016, p. 148). I was interested in Ariane's inspiration to act on the deaths of teenagers using the \#illridewithyou hashtag from Sydney - in that way, the story became its own meta-narrative about what had been considered important in the space of one week in December 2014. Ariane herself had identified silences in the present and recent past, and the power dynamics behind it, when she noted how media coverage and Indonesian audience attention of the Lindt cafe 
hostage siege in Sydney, and the resulting \#illridewithyou hashtag, trumped reportage of the killings of teenagers in her own country.

By the time I had pitched the documentary to the ABC in 2019, it became clearer what the story might be. Some of those I had interviewed in 2015, including human rights lawyer Veronica Koman, had become key players in the largest protests on West Papua in decades, which began in August 2019. I realised I could seek to translate how Indonesia's response to West Papuan grievances had tracked in the past, but particularly during the last momentous five years, what the roots of these grievances were, and why they had become so visible. I sought to examine this through the personal experiences of three women: Indonesians Zely Ariane and Veronica Koman, as well as West Papuan activist and student Dorkas Kossay, who I had followed and interviewed at different stages between 2015 and 2019. For my reportage, I focused on new critical findings about the Paniai incident released by Indonesia's human rights commission in February 2020, as well as the West Papua protests that swept Indonesia in 2019. I also re-interviewed Koman, who had become a target by the Indonesian Police and was featured in international news headlines because of her tweets documenting the demonstrations. That first Aha! moment that occurred during my interview with Ariane also made it in: \#Illridewithyou became the framing device to add context for an Australian audience, as well as the fact that Koman was now living in Australia, describing herself as being 'in exile'.

\#Illridewithyou, West Papua was an attempt to use this story, not only to appeal to an Australian audience, but to critique this first draft of memory in narrative form. Lindgren and Philips (2016) use Keren Tenenboim-Weinblatt's concept of 'mediated prospective memory' to explain the journalistic process of creating materials than inevitably become collective memories inserted into the public domain (p. 159), as well as 'the process whereby past memories are harnessed in order to raise awareness and encourage future remedial action' (Lindgren \& Philips 2016, p. 160). My reportage for the ABC inevitably engaged in its own mediated prospective memorising by offering a focus on Paniai-in other words, aiming to 'reverse an existing silence' (Nash, 2016, p. 150) and challenge budaya bisu (a mute or silent culture) (Giay, 2006). Another benefit of long-term research and/or reportage was that I was able to witness this silencemaking and reversing in real time, and over time.

An example might be found in the finishing lines of the online article I wrote for the ABC (Lopez, 2020). It used the news peg - that in early 2020 Indonesia's human rights commission had found the military had committed gross human rights violations in Paniai - to illustrate possible (albeit thus far squandered) avenues for justice (Amnesty International, 2020). It also drew on the experience of activist Zely Ariane, whose own life has since become inextricably interwoven with this story and community — she married a man from Paniai, had two 
children and now works as a journalist in the same region. Ariane could recall the recent past, point out which remedial actions had been promised but not yet carried out by the Indonesian government, and the impact that had had on West Papuans themselves. As the article reads:

The Indonesian government has sent mixed signals about last month's finding by the National Commission on Human Rights (Komnas HAM) after its five-year investigation into the Paniai incident.

While the government initially committed to following up on the report, the Attorney-General's Office, which is responsible for instigating prosecution, recently said the commission's findings were incomplete, and that it would return the dossier...

[Ariane] still recalls the speech that President Joko Widodo gave to Indigenous Papuans a few weeks after the Paniai killings.

He told them he wanted the case to be 'resolved as quickly as possible, so that it does not reoccur in future'.

Zely says people have grown weary of seeking justice for what happened.

'They just focus on their wounds. They know that the legal process won't deliver a win,' she said.

'They feel numb. And the situation [in Papua] since Paniai has only become worse.

'There have been too many new tragedies, new arrests, and far more deaths than the four people who died in Paniai.' (Lopez, 2020)

\section{Reversing silences through audio documentary}

I want to reflect a little more about the power of journalism to reverse silences through translation - particularly through a style of audio documentary that is narrative-led and often considers the past and memory in telling a current-day story. ${ }^{2}$ I argue that speaking and listening specifically work to challenge such silences, and also have roots in West Papuan memoria passionis. Giay (2006, p. 31) suggests a number of ways West Papuans counter the silence of budaya bisu: including through the performance of songs and oration; seminars, book reviewing and discussions; worship and drama.

\#Illridewithyou, West Papua is available in transcript form below, but I will focus on a scene in the documentary that can only be completely appreciated by listening to it.

\section{LISTEN TO SCENE: belindalopez.net/dorkas/}

In the scene, Papuan activist Dorkas Kossay addresses an Indonesian audience in Jakarta during a feminist event, to speak about the experiences of West Papuan women.

From the moment I first heard Kossay's speech, while I recorded it live in 
Jakarta, it stayed with me as a powerful act of oration, infused with the repetition and lilt of poetry delivered in stanzas. Veronica Koman, who was also in the audience, described those listening as being 'mesmerised' by what she was saying:

I am one of the many women in Papua

who every day shed tears,

Because every day,

we see that our children are killed

Our husbands are killed

Our relatives are killed.

It is not only lives that are lost.

Our fields of food are seized

We're evicted from our lands

For palm oil plantations

Our farms are taken

For the paramilitary police.

As radio producer and journalist academic Siobhán McHugh (2012a) notes, audio documentary itself is an aesthetic blend of 'art and journalism', and its focus on narrative, or storytelling, includes the search for such features in an interviewee's speech (p. 198). She turns to affect theory, which has its roots in psychology, to explain how 'an affecting testimony will also arouse strong feelings in the listener, which will, in turn, influence how the listener processes the story and evaluates its meaning (cognition)' (p. 195).

What struck me about Kossay's oration was the affect it produced, in myself and other listeners, although the bare facts in the speech's content are available in human rights reports about West Papua. These are often written in the empirical, straight-laced style of the genre, rarely accessed by a mainstream public and once again employing a kind of 'god trick of seeing everything from nowhere' (Haraway, 1988, p. 581; Kirksey, 2012).

In \#Illridewithyou, West Papua, rather than invoke 'the view from nowhere' and replace each line in Kossay's speech with a reference to the corresponding human rights reports that quantify and classify the Papuan deaths and land evictions that she evokes, her oration stands up on its own. It offers what journalist and writer Rebecca Solnit describes as 'one of the arts of perspective': 'to see yourself small on the stage of another's story, to see the vast expanse of the world that is not about you' $(2014$, p. 29). Or rather, to hear the vast expanse of the world that is not about you. Perhaps it is no coincidence that the audio documentary offers insight through affective listening, since, as Haraway (1988) reminds us, 
the sensory system of vision has been most used to signify 'a conquering gaze from nowhere' (p. 581).

Remarkably, given the poetic, flowing nature of her speech, Kossay later told me she hadn't prepared what to say for the audience: 'I just said what was in my head', she told me. 'And this situation is something we always experience - it's an everyday situation, so [the speech] just came out'. In other words, Kossay needed no preparation because she drew on her expertise, her situated knowledges, as Haraway (1998) would describe them, to communicate with audiences - the Indonesian one, first off, and then an Australian one, indirectly through \#Illridewithyou, West Papua.

I took care to include as much of Kosssay's speech as possible in the documentary. My intention was to have the audience experience her original oration, if not directly through its Indonesian language content, but then through its affect. I had initially hoped to have a West Papuan English-language speaker perform the voiceover, but for logistical reasons instead commissioned performance poet Melanie Senter, based in Sydney where the documentary was produced. During the recording we aimed to translate not only the meaning of the words but its expression and inflections at every moment of Kossay's delivery, which manages to be softly spoken, while smouldering in its intensity. I took considerable time to edit the English voiceover in an 'echo' form sitting not on top of Kossay's oration, but among it, so that the listener might be made to feel they could understand her original words, spoken in Indonesian. The time given to this endeavour, both in recording and editing (and in research time in terms of long-term ethnographic fieldwork supported by the academy), is not common in most forms of journalism (Bacon, 2011). It is one example of how I believe the affective power of audio documentary can strive to make sure that situated knowledges are not lost in the translation work required in journalism.

Of course, the act of translating between languages, of my having translated Kossay's speech from Indonesian to English, is perilous in itself, as Tejaswini Niranjana (1992) and many others have pointed out. Translation, particularly ethnographic translation, risks the same kind of unequal power relations that Trouillot, Giay, Nash and others have identified in history and journalism. Haraway (1988) has the last word, warning that science (substitute with journalism) 'has been a search for translation, convertibility, mobility of meanings, and universality - which I call reductionism only when one language (guess whose?) must be enforced as the standard for all the translations and conversions' (p. 580). I argue that journalism translation must serve to do the opposite - to avoid reductionism and ensure that these 'maps of meanings' mark out multidimensional tensions and reasonances, à la Haraway (1988), as opposed creating a new rendition of the 'totalising classification' of the colonial maps of old (Anderson, 2006). Despite the perils of translation, the audio documentary offers an opportunity to expand 
our 'habitus of listening' with new dimensions and reasonances.

Kossay reflected on effect in a later interview with me, when I asked if she felt the Indonesian audience had really understood what she was saying during her speech. While Kossay was speaking in Indonesian to an Indonesian audience, she too was performing translation or code-switching work, including language translation between the style of Indonesian spoken in the capital, logat Papua (Papuan dialect) and bahasa daerah ('local language' - in Kossay's case, from Wamena in the central highlands of Papua). As \#illridewithyou, West Papua aims to demonstrate, the knowledge translation work on West Papua is also necessary for Indonesian audiences receiving limited perspectives from national media and education systems. Kossay was unsure about whether her audience was capable of understanding: 'How can they understand what life is like for us there? And even if they can feel it, after they hear it, what will they do about it?" she asked. She might also have asked the same of an Australian audience.

However, Sue Tait (2011) critiques the attempt to elicit affect in 'bearing witness' accounts in journalism that 'moralises the audiences' future action' (p. 1227). (In Kossay's words: 'Even if they feel it, what will they do about it?'). Tait argues the danger is that the empathy elicited for the victim creates a straw man Evil Other that misrepresents complexity, and is responsible for 'reproducing the mechanisms of violence rather than facilitating processes of reconciliation' (p. 1233). (My hope was to avoid this by conveying the multiplicity and complexity of Indonesian views and responses to West Papua, as well as useful Indonesian and Papuan exchanges and identifying proposed legal avenues for justice). Despite Tait (2011) arguing that it is 'difficult to conceive of a journalism that is at once objective, and able to "nourish moral response"" (p. 1232), other journalist-researchers have articulated the consistency of these two positions. Jake Lynch (2015) posits that (peace) journalism's task is to create opportunities for readers and audiences to 'consider the value of non-violent responses', but — 'if such responses — once considered — are rejected, "there is nothing else journalism can do about it, while remaining journalism"” (pp. 193-194).

I argue that affect is important in reversing silences on underreported issues, such as those that take place in West Papua. Nash (2013) writes that the answer to 'what's the story' - the research question in journalism - can adopt a number of modes (p. 129). The audio documentary allows for an affective mode, as opposed a statistical representation of deaths and crimes often found in reporting about West Papua. McHugh (2012a) argues that an experience narrated in an "affecting way" allows listeners to "translate" the emotion through the prism of their own lived experiences; we can infer that this personalisation will confer added impact' (p. 195) (text changes mine) —-we might also call this an expansion of our 'habitus of listening'. In that way, the audio documentary can evoke an empathy 'map of meaning', to refer to Stuart Hall et al. again, as a 
translation tool for the audience to drill down into the root of Papuan grievances. Such affective translation work is the great humanising force of journalism. Trouillot (2015) reminds us that the production of silences during colonialism and slavery required feigning that 'resistance and defiance did not exist, since to acknowledge them was to acknowledge the humanity of the enslaved' (pp. 82-83) - a critique reflected by Kossay and her friends in \#Illridewithyou, West Papua: 'These people, they don't see us as humans, do they?'

'Good journalism' instead 'enables power to be inspected and interrogated' and 'challenges accepted notions of "us" and "them"' (Lynch, 2013, pp. 6, 19). Human rights lawyer Veronica Koman told me that Indonesians witnessing accounts of Papuans expressing their grievances amongst a heavy response by security forces during the 2019 uprisings, through mainstream and social media, led some to better understand and acknowledge Papuan perspectives: 'This is enough,' she said of their reaction. 'They are not being treated as humans.' (Figure 2)

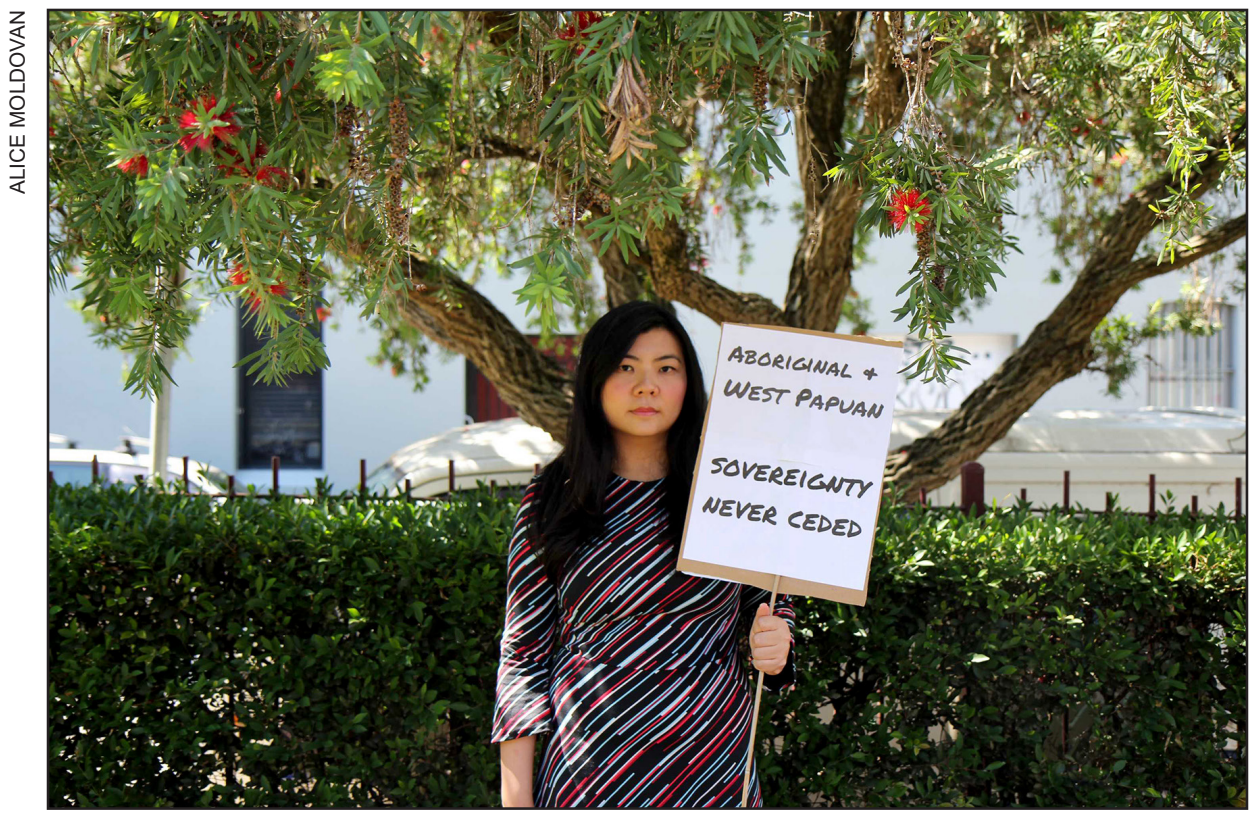

Figure 2: Human rights lawyer Veronica Koman believes that Indonesians witnessing accounts of Papuans expressing their grievances [during the 2019 Uprising] ... led some to better understand and acknowledge Papuan perspectives. 


\section{Part 2: The podcast}

First broadcast by ABC Radio National's Earshot documentary programme: https://www.abc.net.au/radionational/programs/earshot/iillridewithyouwest-papua/12005696

\section{\#IIIridewithyou, West Papua}

By Belinda Lopez

EARSHOT HOST: It feels like centuries ago in internet years, but do you remember the hashtag \#l'Iridewithyou?

When Man Monis took hostages in the Lindt cafe in Sydney, in the name of Islamic State, Australian Muslims were scared of a backlash. Some were worried about taking public transport.

Hashtag 'I'll ride with you' was a way of saying 'we're with you'. A week before the Lindt cafe attack, something else terrible happened, that attracted far less media attention. It was in the most remote part of Indonesia, West Papua. But there is a link between these two events.

.... On today's Earshot, we're asking, how do you make people care about issues that are usually ignored, or even censored?

Over the past few years, researcher Belinda Lopez has been following three women in Indonesia, who've decided they had to speak out about West Papua. But the topic is so sensitive that just

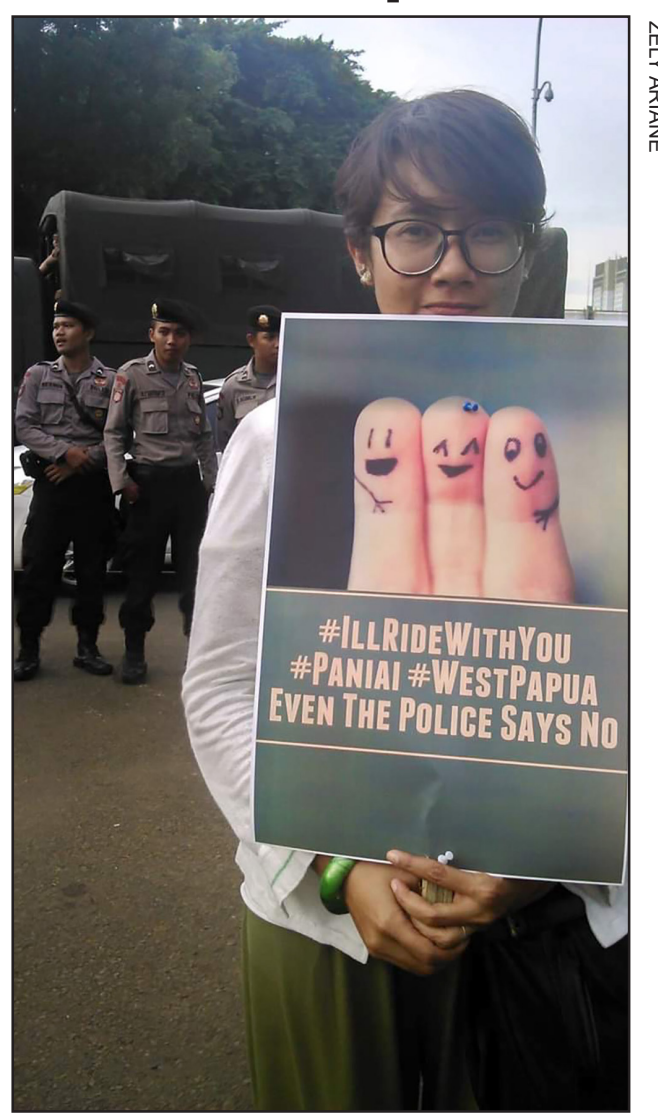

Figure 3: Activist Zely Ariane helped organise a tiny demonstration in the middle of Jakarta. She stood there with other activists, holding up that poster. protesting means you can be arrested. In the demonstrations that swept through Indonesia last year, hundreds were.

But this story begins in December 2014, just as I'Il Ride with You started going viral.

BELINDA: Something about 'I'll ride with you' spoke to people-maybe it's 
the idea that you can support someone different to you. And-it's pretty easy to share a hashtag.

[AUDIO NEWS CLIP: 'Tell us the story of I'll Ride With You...']

BELINDA: It was trending worldwide. Including in Indonesia's capital, Jakarta.

ZELY ARIANE: [Indonesian] Pas di Australia, itu ada yang I'll Ride with You, gitu (In Australia, there was I'll Ride with You).

BELINDA: This is activist Zely Ariane (Figure 3).

ZELY: Hashtag 'I'll ride with you' was all over social media. That was in December, soon after Paniai happened.

BELINDA: In Paniai, West Papua, four teenagers were killed by Indonesian security forces, who opened fire into a crowd, according to human rights groups. Police said they were just defending themselves from violence. The crowd had gathered to protest what had happened the day before. Members of the military allegedly tortured a 14-year-old.

But Zely could see online that people in Jakarta were paying more attention to l'll Ride with you- in Sydney.

ZELY: So we made a poster of it— I'll ride with you, Paniai, West Papua.

BELINDA: She helped organise a tiny demonstration in the middle of Jakarta. She stood there with other activists, holding up that poster. Indonesian lawyer Veronica Koman also helped out.

VERONICA KOMAN: I was already disturbed by West Papua issues anyway, and then because the victims were children really outraged me. From that time, we agreed that we need solidarity in Jakarta, based in Jakarta. Like I tried to find West Papuan activists in Jakarta and then we gathered, and then: Let's make a movement, which is called Papua Itu Kita.

BELINDA: Papua Itu Kita. It means Papua is Us. And that poster I'll Ride with You, West Papua - was their first logo on social media. Zely, Veronica and a group of Papuans and Indonesians had a clear aim-this is Zely speaking to me back in 2015.

ZELY: We want to build a bridge for people in Jakarta, and for people all over Indonesia, who don't know about Papua. There's a lot of stigma and prejudice. And sometimes it's not because Indonesians are racist, it's because they just don't understand.

BELINDA: I was there, at the first event Papua Itu Kita put on in Jakarta in 2015. Zely was the MC.

ZELY: [at event]: I'm Zely Ariane. The phone number on the poster, that's 
my number. Now, from around seven, the music is going to be really good if you're on a date, ok? So invite your lover to come along...

BELINDA: You can hear it in Zely's tone: She was open and enthusiasticand non confrontational. Papua Itu Kita shared Papuan art, and culture and politics-carefully.

ZELY [at event]: So friends, it's like this: We at Papua Itu Kita haven't worked together for very long. This is our first event-and we want it to be something that makes all of us in Jakarta feel close to Papua.

BELINDA: The thing is, in Indonesia, recognising Papua is seen as political. This is about history. After Indonesia gained its independence from the Dutch in 1945, it fought for Papua be included in its territory. And so Papua somehow completes Indonesia's idea of itself as a nation.

The government says it's done a lot to develop Papua.

But that's not how a lot of Papuans see it. Papua was also a Dutch colony, and many say it only became a part of Indonesia because of a UN-backed election in 1969, which has since been called corrupt.

And they say Indonesian security forces have rarely been made accountable for human rights abuses against them-for decades.

And the most outspoken Papuans say publicly what even more say privately: that the solution is for West Papua to become its own nation.

But that can see you charged with treason.

BELINDA: Soon after Papua Itu Kita got started, the team began meeting at the Jakarta Legal Aid Institute, LBH. It's an unassuming building in the middle of the city. I spoke to Veronica there in 2016, when she was working as a legal aid lawyer.

VERONICA [chatting in background]: ... pro-bono stuff...

BELINDA: LBH has always supported freedom of expression, so Papua Itu Kita figured it would be good place to hold an event-where Indonesians could hear what Papuans actually wanted. Then one of the MCs started to get the crowd involved.

VERONICA: ...And he said: Ok when I say Papua, you say 'Itu Kita'. Or for those who want to say merdeka. you can say it.

BELINDA: Merdeka is the Indonesian word for freedom.

VERONICA: So Papua Merdeka already said, like really enthusiastically 'Papua merdeka, Papua merdeka' three times in this office. And on that event there's so many intels (laughs).

BELINDA: 'Intel' is short for Intelligence officers. Veronica said they all seem to kind of dress the same. 
VERONICA: And they're wearing their distinctive polo shirt. They're not in their, uh, official uniform but even in front of LBH Jakarta right now, I can say, that half of them are intels.

BELINDA: Every time I went into the legal aid building, l'd see men, sitting outside, watching.

VERONICA: And they're getting more intels since LBH Jakarta takes West Papuan issues. And because West Papuans are hanging out in our office and West Papua issues just like intel magnet.

BELINDA: In Jakarta, young Papuans would often tell me they felt extremely visible. There was the political surveillance, sure, but it was more than that.

They escaped to their student boarding houses, to hang out. Some prayed together, others talked politics.

[AUDIO: Papuan students singing in a shared rented house in Jakarta].

BELINDA: At school back home in West Papua, they were constantly told they were Indonesian. But when they arrived in the capital, they weren't always made to feel that way.

DORKAS KOSSAY: Maybe they felt I was different, or that I was somehow... I don't know. They would always ask, 'Hey Dorkas, can we touch your hair?' 'Yeah sure,' l'd say. 'Just touch it.'

BELINDA: When I first met Dorkas Kossay in Jakarta, in 2016, she told me she was the only Papuan in class at university, and the other students would stare at her black skin and curly hair.

And when I asked her what it had been like living in Jakarta, she started telling me this story, about when her friends from Papua had come to visit for a student conference.

DORKAS: These were friends who hadn't been to Jakarta before. So I said, 'let's go check out Jakarta'. My friends wanted to rent a car to be more comfortable but I said 'No. You've got to understand how the people here treat us'.

I wanted to see what happened when these Papuan friends of mine got on the train, with these massive dreadlocks in their hair.

When they got on, straight away the women who were sitting nearby who were all wearing headscarves, they held their headscarves like this, against their nose, and I thought, "Wow, didn't my friends take a shower?"

Oh God, straight away I felt emotional. I said to the women: 'Ah, excuse me mam, sorry, actually l've got a face mask in my bag, do you want to use it? Instead of making your headscarf dirty, you can just use this mask.' 
And the woman said, 'Oh, no, no miss, no. No don't worry about it, don't worry.' And the way they were acting, just made us feel so unwelcome.

Papuans like me who have been here a long time are used to this, but these guys who had just arrived, they were really angry. They said: 'These people they don't see us as humans, do they?'

ZELY: I've got a public mobile number and I'm always getting calls in the middle of the night. There's just silence on the other end. I say, 'Hello, hello, hello' three times, and then if I don't hear anything, I just hang up. Do I feel scared? No, I mean, maybe because I haven't received any serious threats yet. But all my activities are out in the open. It's not like I'm sharing hardcore posts about Papuan independence on Facebook.

BELINDA: I'd met up with Zely for a drink after she'd just come back from a remote part of Papua. She was leaning out of the window, looking out at the Jakarta traffic.

ZELY: I want to go back to Papua. Look, basically: The more that is known about Papua. The subtle details we know about Papua and its problems, and the more that's spoken about in Jakarta, the more things will improve. It's not like, 'Oh, I want to move to Papua because it's so pretty'-no, it's not like that. I need to stay there longer to understand.

***

BELINDA: When Veronica Koman was 19, she did what a lot of us have done: she got a tattoo, that she later sort of regretted. We were at her office, LBH, when she showed me her forearm, inked with the word 'Indonesia'

VERONICA: It's the philosophy that Indonesia is running through my veins. I was a crazy nationalist.

BELINDA: After years studying in the national education system, Veronica was a passionate defender of Indonesia and its red and white flag, the Merah Putih.

VERONICA: Like even when I was in the car and I saw a Merah Putih flag, I could just raise my hand like this. On the 17th of August, the independence day of Indonesia, I could just listening to this nationalistic music-it's like crazy, it's fascist or something. And (laughs) I was actually embarrassed telling this story.

BELINDA: Every country has its national stories. One of Indonesia's stories is that it liberated Papua from Western colonialism. So when Indonesia was criticised internationally about West Papua, Veronica used to think that it was just more Western colonialism—against Indonesia. 
VERONICA: Like now, this West Papua issue-separatism - it's just a US conspiracy. And now I tell my colleagues now too, if you look for anything in Bahasa Indonesia you will not find anything about the human rights abuses in West Papua. But if you google in English, then you can find the truth.

BELINDA: The Indonesian government heavily restricts foreign journalists and NGOs from going to Papua, but that hasn't stopped decades of reports of human rights abuses from coming out. Instead of searching for 'Papua' in Indonesian, Veronica typed 'West Papua' in English, and what she read was totally different to what she'd learned at school, and in the media.

VERONICA: I remember reading all this, like 'what, what is this really true?' But oh, this is from the reliable sources'. I was being brainwashed, Indonesians are being brainwashed and [subject to] systematic censorship.

***

BELINDA: A couple of weeks after I spoke to Veronica, I went to a history conference at LBH. There were a lot of political discussions planned- including about longstanding problems in Papua.

Zely was there presenting. When I left LBH I must have forgotten to switch off my recorder.

[Rustling zipper]

Just as I walked outside, I ran into another Papuan activist I had met earlier. And almost immediately, an Indonesian man, dressed in a polo shirt, interrupted our conversation. You can just make out him asking me where we're both from.

[BELINDA (faintly on tape): Australia]

Then [the] poloshirt guy asked me if I was a journalist. And if I'd been to Papua? No, I said. I was actually doing my $\mathrm{PhD}$, and I had been to Papua years before-but I didn't trust this guy. He was dressed exactly how Veronica described the intelligence officers. She said they claimed to be journalists (Figure 4). He told me he was part of the press. So what do you report on? I asked him.

[BELINDA (faintly on tape): So what do you report on?] Everything, he said.

[BELINDA (faintly on tape): OK. Nice to meet you. Bye bye.]

$* * *$

BELINDA: One of the times I felt the huge abyss between West Papua and Jakarta was when I saw Dorkas speak in front of an audience. It was for a feminist event, in Jakarta. Veronica was there as well. She asked the organisers to let Dorkas speak. 


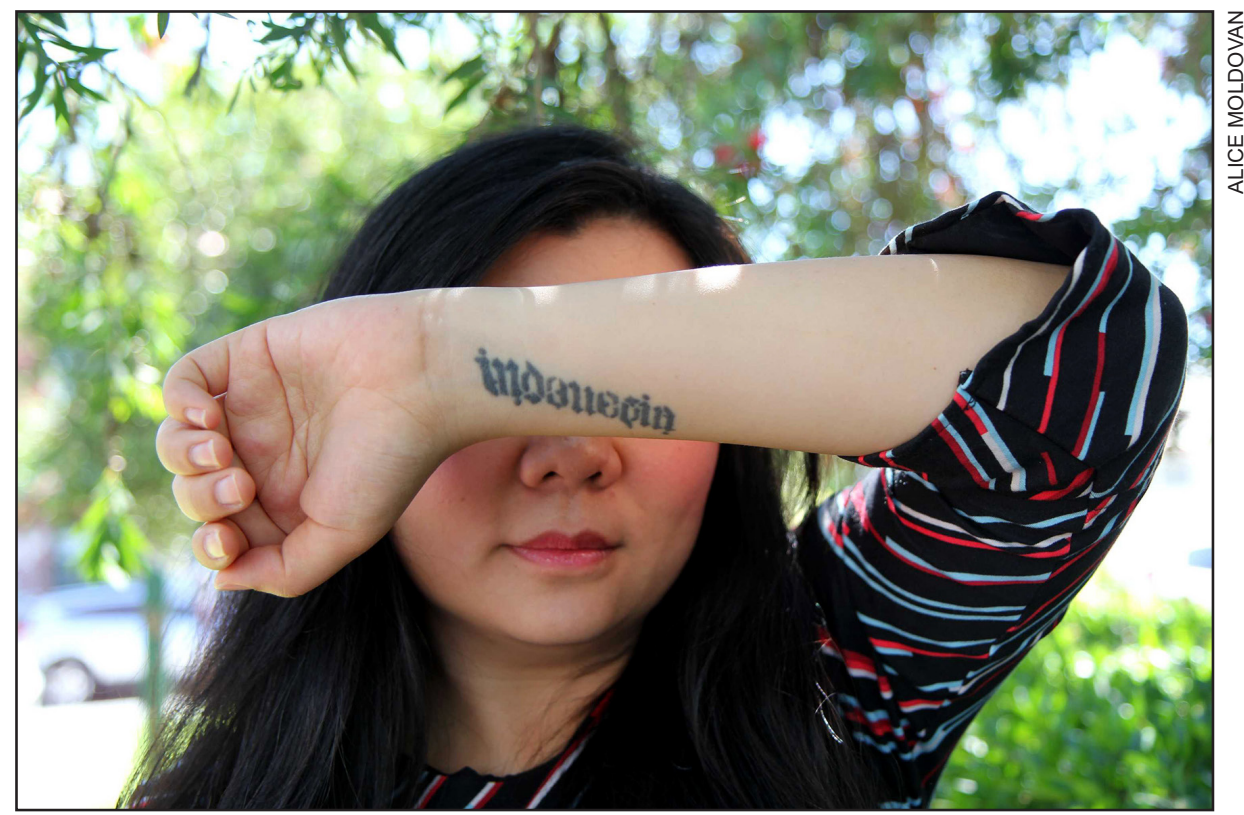

Figure 4: Human rights lawyer Veronica Koman with her distinctive Indonesia tatoo on the left arm: Intel - intelligence officers - all seem to kind of dress the same'.

VERONICA: Among West Papuan students, Dorkas was the most articulate and powerful one.

BELINDA: The MCs were really high energy.

[MC, screaming: ... Kakak (Sister) Dorkas! ]

BELINDA: Dorkas got up on the stage wearing a high tall headdress made from cassowary feathers, a native bird of Papua.

VERONICA: Before she started to speak she told me she was nervous. But then the audience was mesmerised to what Dorkas was saying.

DORKAS: Good evening everyone [softly]

Good evening everyone [louder]

[Crowd: Malam! (Good evening!)]

Thank you.

I am one of the many women in Papua who every day shed tears,

Because every day, we see that our children are killed

Our husbands are killed

Our relatives are killed.

It is not only lives that are lost.

Our fields of food are seized 
We're evicted from our lands

For palm oil plantations

Our farms are taken

For the paramilitary police.

Thank you friends, that's all from me.

BELINDA: Later, I asked Dorkas if she felt the audience had understood what she was describing.

DORKAS: I have my doubts. Could they really, really feel what I was saying? Or not? How can they understand what life is like for us there? And even if they can feel it, after they hear it, what will they do it?

When I went back home and saw Papua the way it is, and then Java the way it is, it made me think differently. I felt that, yeah... Papuans must be free.

BELINDA: It's been five years since the Paniai incident, where teenagers were allegedly killed by Indonesian security forces. No one's been prosecuted since their deaths.

It's also five years since the l'll ride with you hashtag, and the Lindt Cafe terrorist attack in Sydney. And I'm actually standing just 200 metres from the Lindt café and Veronica Koman is here, protesting in front of the Australian Department of Foreign Affairs and Trade.

She says it's not safe for her to go back home to Jakarta.

[Veronica on megaphone: 'We really need your solidarity. It's very heartening. This is my first protest on West Papua issues together with Australian comrades']

BELINDA: Recently, other Indonesians have held counter-protests against what they say is an attempt to break up Indonesia.

[Protesters: 'Free the Jakarta Six, end the repression now, Free the Jakarta Six, end the repression now...']

BELINDA: 'The Jakarta Six' are five Papuans, and the first Indonesian currently on trial for treason for declaring their support for an independent West Papua [CKD].

[Veronica on megaphone: ...'and they're facing 20 years imprisonment for that. And what do we hear from Australia?'

Crowd: 'Nothing!']

BELINDA: Another 50 ethnic Papuans will also be tried for treason. It started last year in August, in the week of Indonesia's independence day. Veronica used to play nationalistic songs, but last year, she was the lawyer for Papuan students threatened by nationalist groups at their student dorm. 
The Papuans were accused of damaging an Indonesian flagpole. Veronica was on the phone to them when police stormed their boarding house.

She tweeted about it. Videos of what happened went viral on social media.

What came next were the largest protests about Papua that had been seen around Indonesia, in decades.

It just felt like the heat had been turned up on something that was simmering for years.

By then Veronica had moved to Australia to do her masters. She spent her days online, documenting the demonstrations on Twitter. And then, in West Papua...

VERONICA: The Indonesian government shut down the internet. I think it was to prevent the footage and information of thousands of West Papuans took to the streets demanding independence referendum from coming out to the world. So they shut the internet down. But I managed to keep getting the footage and then I kept posting it... Jakarta already said that the situation in West Papua has gone back to normal but I kept posting these videos, which makes their claim not true.

Not long after that they named me as a suspect based on four different laws, from spreading hoaxes and then incitement to riot because of my posting. [Police reading Veronica's tweets]

BELINDA: This is the head of the East Java police reading out Veronica's tweets at a press conference. He calls her a provocateur.

The police have threatened to cancel her passport and put out an Interpol red notice, to have her brought back to Indonesia, from Australia.

VERONICA: But I think, I think these fabricated charges against me is just a way to shut me up in general about this whole uprising thing.

BELINDA: Veronica's Twitter profile now reads: Human Rights Lawyer, in Exile.

VERONICA: Like I sort of knew I would be arrested sooner or later, or in exile. Ah, actually I didn't expect that I would be in exile. Yeah. (laughs).

BELINDA: I mean, you laugh about it, because it's kind of one of those 'if you don't laugh you'll cry' sort of things.

VERONICA: Oh, yeah, yeah, yeah. A friend pointed that out to me. He said that 'there's always new bad things happen to you. But you always tell me the story while laughing it off hahahaha'. Yeah, I think it's some sort of reaction, I don't know (laughs).

BELINDA: Do you allow yourself to think about that, in terms of the very real possibility that you might not be able to return to Indonesia, ever again?

VERONICA: Ah, I think even if they drop the charges, but still, thanks to the 
drama of the Indonesian police making me everyday headline news everywhere on national media, it could be dangerous for me, especially from the ultra nationalist groups, which are many in Jakarta (laughs). Yeah.

BELINDA: I'm speaking to Veronica in Sydney. A lot has happened since I met her in Jakarta. I found out I'm on an Indonesian government blacklist. It's a really long story that I'm still trying to work out-but I do know that while I'm on the blacklist, I can't go back to Indonesia either.

And a year after Veronica moved to Australia, Dorkas Kossay died.

BELINDA: I want to talk a little bit about Dorkas, if that's ok. I did a search this morning of Dorkas just to see what people said, when she died. And it came up actually with your message that you wrote on Facebook.

VERONICA: Ah, yeah suddenly feel things again. Yep. Yeah. (Whispers) Now I want to cry.

BELINDA: Yeah sorry, she was so brilliant.

VERONICA: Yeah so, I posted 'Kerja terlalu lambat, kolonialisme memberangkat banyak kawan dengan lebih cepat. RIP Dorkas Kossay sayang. ('Working too slow, colonialism has taken away many lives of Papuans friends. Rest in peace, the beloved Dorkas Kossay'.)

Still until now, many West Papuan friends passed away very very young. Including Dorkas. So at that time I felt desperation. I felt guilt that this person that I admire, they passed away before they saw independence.

BELINDA: That's something that's been really shocking to me as well, since I went to Jakarta, and met a lot of different Papuans there. Is just how many of these young, bright intelligent people, the people that would have been the new leaders of a generation of thinkers and artists, from West Papua, and political leaders, just gone. Just, sickness, things that were curable.

VERONICA: Yeah I agree I remember the first few deaths I was so shocked, but now I'm used to it. Sadness of course I still cried every time I heard the news. But it didn't shock me too much anymore. It's partly because West Papuans do not trust Indonesian healthcare system. Err, hospitals. So they prefer to not go to the hospital, that's why they died.

And then, West Papuans who are sick, they tend to not tell anyone about it. Because their life has been so hard, they feel embarrassed, as if they're complaining. So they keep it to themselves. So we don't know we are sick.

BELINDA: In Dorkas' case, did she keep quiet?

VERONICA: Yeah, Dorkas kept quiet and every time a friend dies I always feel like we need to work faster, people are literally dying.

BELINDA: I remember when we spoke three years ago you said Indone- 
sians weren't aware. Do you think more Indonesians now know what's happening in Papua?

VERONICA: Yeah. Because ignorant Indonesians like to say, 'ah it's only a handful of Indonesians who want independence from Indonesia, surely'. But now, because of the footage of thousands of Papuans demanding independence referendum, I haven't heard such ignorant comments since being said again.

Before the uprising began, I felt something different because it was not just coming out from the Papuans, but many Indonesians on social media publicly support: 'They're not being treated as humans, so we support their independence from Indonesia'. Many Indonesians did that on Twitter, and Facebook as well.

BELINDA: On the other hand, social media can be an echo chamber. I mean how reflective do you actually think it is of the wider Indonesian society?

VERONICA: It's still a small group of people but there were Indonesians leading the marches in Java. In Jayapura, Sorong, and Wamena, Indonesians were amongst the arrested ones. So on the ground it's real. Like Indonesians are willing to take the same risks.

BELINDA: Could you have imagined the support that you've seen amongst Indonesians when we spoke three and a half years ago?

VERONICA: No, that's a very good question. No, no, I didn't imagine it. No. Oh my God, I now feel a little bit teary. That's right, I didn't imagine that at all. We've come so far. 


\section{Notes}

1. West Papua refers to two administrative provinces in Indonesia, Papua and West Papua. West Papua is also the name by which the two provinces are collectively known internationally in English, often alluding to its self-determination aspirations.

2 McHugh (2012b) describes a similar form as the 'crafted oral history radio documentary'.

\section{References}

Amnesty International. (2020, February 24). Indonesia: Launch independent and effective investigations into unlawful killings in Papua, Including in Paniai and Galunggama, Sugapa district. Retrieved from https://www.amnesty.org/download/Documents/ ASA2118522020ENGLISH.pdf.

Anderson, B. (2006). Imagined Communities: Reflections on the origin and spread of nationalism. London and New York: Verso.

Anderson, R., \& Killenberg, G. M. (1992). Journalistic listening and 'slanted empathy': Ethical implications of the Janet Malcolm accusations. International Listening Association Journal, 6(1), 66-82.

Bacon, W. (2011). Investigative journalism in the academy-possibilities for storytelling across time and space. Pacific Journalism Review, 17(1), 45-66. https://doi. org/10.24135/pjr.v17i1.371

Bacon, W. (2012). Frontline: An innovative direction in academic journalism. Pacific Journalism Review, 18(2), 153-165. https://doi.org/10.24135/pjr.v18i2.270

Becker, J. (2004). Deep listeners: Music, emotion, and trancing. Bloomington: Indiana University Press.

Giay, B. (2006). Pembenuhan Theys: Kematian HAM di Tanah Papua. Yogyakarta: Galang Press.

Hall, S., Critcher, C., Jefferson, T., Clarke, J., \& Roberts, B. (1982). Policing the crisis: Mugging, the state, and law and order. London \& Basingstoke, UK: Macmillan Press.

Haraway, D. (1988). Situated knowledges: The science question in feminism and the privilege of partial perspective. Feminist Studies, 14(3), 575-599.

Human Rights Watch. (2020). World report 2020. Retrieved from https://www.hrw.org/ sites/default/files/world_report_download/hrw_world_report_2020_0.pdf.

Kirksey, E. (2012). Freedom in entangled worlds: West $\bar{P}$ apua $\overline{\text { and }}$ the architecture of global power. Durham \& London, UK: Duke University Press.

Lindgren, M., \& Phillips, G. (2016). Asbestos memories: Journalistic 'mediation' in mediated prospective memory. In C. H. Lohmeier \& C. Andrea Pentzold (Eds.), Memory in a mediated world: Remembrance and reconstruction (pp. 158-172). New York, NY: Palgrave Macmillan.

Lopez, B. (2019). Finding Papua in Java: Papuans tell stories about the past and themselves. (Unpublished doctoral thesis). Macquarie University, Sydney.

Lopez, B. (2020, March 23). The Indonesian women speaking out about West Papuawhatever the cost. Australian Broadcasting Corporation. Retrieved from https://www. abc.net.au/news/2020-03-23/illridewithyou-indonesians-cost-of-talking-about-westpapua/12049936.

Lynch, J. (2013). A global standard for reporting conflict. London: Taylor \& Francis Group.

Lynch, J. (2015). Peace journalism: Theoretical and methodological developments. Global Media and Communication, 11(3), 193-199. 
McHugh, S. (2012a). The affective power of sound: Oral history on radio. The Oral History Review, 39(2), 187-206.

McHugh, S. (2012b). Oral history and the radio documentary/feature: Introducing the 'COHRD' form. The Radio Journal: International Studies in Broadcast \& Audio Media, 10(1), 35-51.

Nash, C. (2013). FRONTLINE: Journalism as a research discipline. Pacific Journalism Review, 19(2), 123-135. https://doi.org/10.24135/pjr.v19i2.221

Nash, C. (2016). What Is Journalism? : The art and politics of a rupture. London, UK: Palgrave Macmillan.

Niranjana, T. (1992). Siting Translation: History, post-structuralism and the colonial context. Berkeley, Los Angeles \& Oxford: University of California Press.

Rossmanith, K. (2013). The magistrate and Mr Moore: Story-telling, narrative forensics and a judge's experience of sentencing. TEXT, Special Issue 18, 1-13.

Solnit, R. (2014). The faraway nearby. New York, NY: Penguin Books.

State Coroner of NSW. (2017, May). Inquest into the deaths arising from the Lindt Café siege: Findings and recommendations. Glebe: Coroners Court of NSW. Retrieved from http://www.lindtinquest.justice.nsw.gov.au/Documents/findings-andrecommendations.pdf.

Tait, S. (2011). Bearing witness, journalism and moral responsibility. Media, Culture \& Society, 33(8), 1220-1235.

Trouillot, M-R. (2015). Silencing the past: power and the production of history. Boston, MS: Beacon Press.

Tsing, A., and Ebron, P. (2015). Writing and rhythm: Call and response with Anna Tsing and Paulla Ebron. Journal of the Royal Anthropological Institute, 21 (August): 683-687.

The author wishes to thank Wendy Bacon and Chris Nash for their insightful comments and suggestions on a draft of this Frontline article.

Dr Belinda Lopez is a writer, documentary audio maker interested in anthropology, history and social justice. Her work has been shortlisted for the 2020 Australian/ Vogel's Literary Award, the Australian Human Rights Awards and Amnesty Media Awards, and awarded prizes from the United Nations and the New York Festivals. She received her doctorate from Macquarie University in 2020. notes@belindalopez.net 